Article

\title{
Contributions of Organizational Levels in Community Management Models of Water Supply in Rural Communities: Cases from Brazil and Ecuador
}

\author{
Anna V. M. Machado*(D, João A. N. dos Santos, Lucas M. C. Alves and Norbertho da S. Quindeler \\ Departamento de Desenho Técnico, Escola de Engenharia, Universidade Federal Fluminense (UFF), \\ Rua Passos da Pátria, 156, Niterói, RJ, CEP 24210-240, Brazil; joaoalbertoneves@gmail.com (J.A.N.d.S.); \\ lucasmcarneiroalves@gmail.com (L.M.C.A.); norberthosq@id.uff.br (N.d.S.Q.) \\ * Correspondence: annav.machado@gmail.com; Tel.: +55 21 98112-3070
}

Received: 21 December 2018; Accepted: 6 March 2019; Published: 15 March 2019

\begin{abstract}
The community management model of water supply systems has reached a great number of rural settlements worldwide, especially in developing countries. Its functionality, however, has proven to be a major challenge once the stakeholders responsible for maintaining the service fail to provide the technical, financial, and social resources necessary to secure its sustainability. A number of fragilities are associated with a lack of political recognition of community organizations. In some cases, community organizations have been able to maintain strong recognition in decision-making processes through the establishment of associations involving several community organizations, representing a second organizational level. A third organizational level is achieved once these associations reach an extensive area of a territory. This article conducted four case-studies in Latin America. The study revealed that the emblematic examples according to scientific literature presented the second and, in one case, the third organizational level, while the others, where several weaknesses are noticed, only presented the first level. Although difficulties still exist in every scenario analyzed, our study supports that the presence of the second and third organizational levels are factors that positively contribute to better outcomes from the community management model.
\end{abstract}

Keywords: rural water supply; community management; Brazil; Ecuador

\section{Introduction}

Water supply systems have increased the number of people with access to drinkable water throughout the world. Rural areas, however, remain poorly covered by these services. These communities are often distant from urban environments, where investment in water and sanitation infrastructure is usually guaranteed [1-3]. In 2015, the Sustainable Development Goals (SDG) were created as a response to the urge to address serious aspects connected to the improvement of quality of life [4]. The sixth SDG proposes to "ensure availability and sustainable management of water and sanitation for all" [5], with eight main targets and twelve indicators as monitoring tools for the assessment of the strategies utilized by each country. One major improvement from the Millennium Development Goals era is the recognition of the "Means of Implementation" (MoI). International cooperation, capacity building, and community participation in the progress on water and sanitation access for all were declared as MoI of the SDG6, being essential for the success of any approach used to achieve the goal. Hence, community management models of rural water supply systems have emerged as possible alternatives to deliver drinking water to remote and rural settlements and, consequently, could offer major improvements to human health and quality of life.

To guarantee the functionality of community-managed water systems, it is essential to apply best practices to the conception, project, construction, operation, and maintenance phases. Moreover, 
these practices must receive technical, financial, institutional, political, and managerial support to assure their efficiency through time [6-10]. In general, these resources are present in urban areas. In rural and isolated settlements, however, they are scarce, as investments in infrastructure, specialized workforce, and external support from private and public entities frequently fail to fulfill community demands. Consequently, as verified in Harvey \& Reed [11] and Chowns [12], community-managed water systems regularly present failures and breakdowns, decreasing water safety and compromising the quality of life of entire rural populations.

Addressing the weaknesses associated with community-managed water systems' failures has been an important topic of research to specialists of the field. Several factors have emerged as critical to ensuring favorable outcomes from community management models. Promoting joint actions between communities and external supporters has proven to be fundamental to maintaining high-quality water services with minimum gaps [13-17]. Thus, the commitment of private and public entities in maintaining close contact with local communities has an important role in the success of community management, as confirmed in cases from Chile, Colombia, Peru, Mexico, Bolivia, and Ecuador [9,18,19]. Besides, transparency and regulation enforcement are crucial to guarantee users' satisfaction and to maintain service quality [20-25]. A solid enabling environment is also a key element for community organizations' functionality, providing the necessary conditions for organizations to formally establish themselves as service providers [26]. The actual impacts and improvements of the establishment of community-managed water systems following these aspects, however, are difficult elements to measure precisely as relatively few countries have decent and reliable data on water quality and availability, especially in rural areas of the least developed nations [4].

Even though there is little concrete evidence about the real benefits of this management model, many authors consider that it is relevant to recognize the standout factors identified in success cases of community management of rural water supply systems and merge them to design explicit frameworks which allocate specific responsibilities to each stakeholder [17,27-30]. In Latin America, many authors have studied emblematic cases of community management. Schweizer \& Brethaut [31] and Mastrángelo \& Almansa [32] described the "Center of Support for the Rural Management of Drinking Water" (CENAGRAP) as a great example of public-community partnership in the water sector of Ecuador. In Brazil, the "Sistema Integrado de Saneamento Rural" (SISAR) has been recognized as an excellent example of regional association of community organizations, being able to provide high-quality services in the State of Ceará [33]. These two examples share a common feature linked to enhancements of political and institutional strength of community organizations, which is the presence of networks involving several local communities.

Castillo [19] points to the recent trend of the formation of associations involving several community organizations as an alternative capable of generating positive results. The author states that these associations are divided into three levels. The first level consists of community organizations responsible for the drinkable water provision of single communities, being accountable for management, operation, and maintenance of the service. The second level emerges when several community organizations merge to create an association, as SISAR. These associations contribute to the provision of technical and management support to individual communities and they can assume responsibility for the operation and maintenance of multi-community systems. Finally, the third level appears when the number of community organizations composing these associations increases to a level where it reaches regional or national scales, as CENAGRAP, representing many local communities. These associations enhance the institutional recognition of community organizations at local, regional, and national levels, improving their participation in decision-making processes and water governance discussions.

This work aims to describe the different organizational structures and stakeholders' roles in four community organization models in Latin America, verifying the presence of organizational levels as presented in Castillo [19]. The information obtained to develop the current work was based on scientific publications, non-structured interviews with specialists of the rural water supply field, technical visits 
of the authors, and technical reports from multi-lateral entities. First, we present a brief scenario about the presence of organizational levels in Latin American countries. Then, a description of the cases selected for this article is provided. Finally, a comparison of each case is displayed in the discussion section, where we demonstrate the allocation of responsibilities in each community management model and the potential benefits derived from the presence of different organizational levels.

\section{Materials and Methods}

\subsection{Motivations and Selection of Cases}

The current paper was developed to demonstrate four cases of community management of rural water supply systems in Latin America. The main motivation for the development of this work was the low number of scientific publications describing the organizational structure of the cases selected in this study. Considering their positive reviews from international entities connected to the rural water supply field of study, this scarcity is a disadvantage to the progress of community management of rural water supply systems, as insights could be derived from a better understanding of their organizational scheme. According to Webster and Watson [34], papers approaching emerging topics with low numbers of publications, even if shorter than usual publications, are valuable information resources for future investigations.

The selection criteria of two of the cases studied, CENAGRAP and SISAR, were based on their recognition by several authors as emblematic examples of this management model [31-33]. The selection of the other two cases was based on the existence of community-managed systems routinely applied in remote communities of the states where they operate and on the existence of technical documents and conference proceedings describing their structure. Thereby, the research presents case-studies from the Brazilian states of Paraná, Espírito Santo, and Ceará and from the Cañar district, in Ecuador.

\subsection{Bibliographic Research}

Considering that scientific publications specifically related to the cases approached in this work are scarce, technical reports and documents from international, regional, and local entities were highly considered as information resources for the current work. Community management models of rural water supply systems in Latin America have recently received the increased attention of academics, whereas thorough descriptions of the organizational structure of community organizations remain underexploited. The bibliographic research relied on "Portal Periódicos da Coordenação de Aperfeiçoamento de Pessoal de Nível Superior", which is a search engine created by the Brazilian government to promote knowledge development in Brazilian higher education institutions. The engine grants Brazilian researchers access to a variety of databases, such as Scopus and Web of Sciences. To expand the possible outcomes from our bibliographic research, Google Scholar and other relevant documents and papers were also used.

To outline this review, Webster and Watson [34] and Preferred Reporting Items for Systematic Reviews and Meta Analyzes (PRISMA) [35] were used as guidelines. Our research considered a 10-year timespan starting from 2019; however, relevant documents from years earlier than 2009 were also included. Moreover, publications in languages other than English, Portuguese, and Spanish were not considered. The keywords used to generate the publications cited in this paper were "rural water supply", "rural water supplies", "community management", "community managed", "Latin America", "SISAR", “CENAGRAP", “CESAN", “SANEPAR", "autogestão", "gestão comunitária", "abastecimento de água em áreas rurais", "gestión comunitaria" and "abastecimiento de agua en comunidades rurales". Consequently, a total of 892 documents were exposed. From these, 194 duplicates were excluded. Subsequently, the authors performed a title screening to exclude documents with titles irrelevant to the subject, which resulted in the elimination of 460 publications. Then, the authors executed a thorough analysis of the abstracts of the remaining documents, which 
allowed a better understanding of the emphasis that each document possessed. The rural water supply field of study covers a wide variety of specific topics, such as water systems technologies, gender equality, and public health. Thus, 75 documents with irrelevant topics for the purpose of this work were rejected. Finally, 163 documents were fully examined, with 100 publications being removed because of results unaligned with the scope of the current work, and, ultimately, 63 documents were considered to formulate the current paper. The flow diagram illustrating the process described if demonstrated in Figure 1.

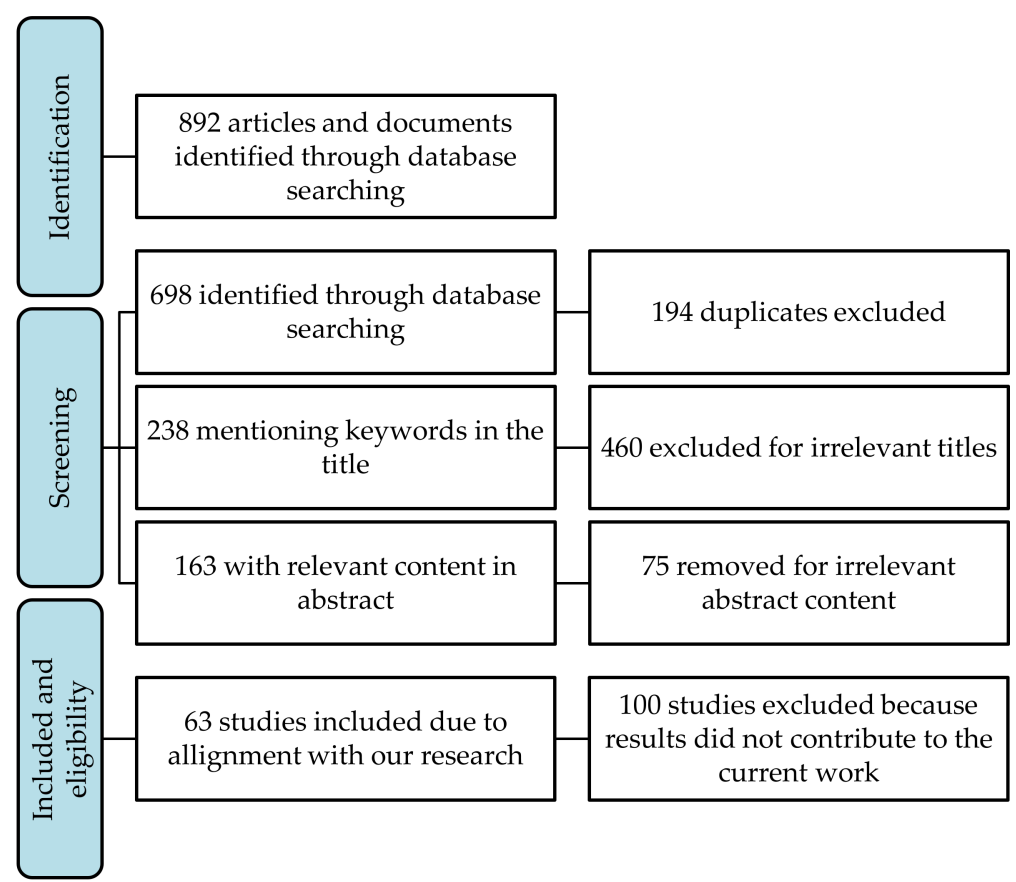

Figure 1. Flowchart identifying steps performed for the literature research using PRISMA methodology.

\subsection{Data Collection}

Part of the data was collected during technical visits in Paraná in 2015 and in Espírito Santo and Ceará in 2015, 2016, 2017, and 2018. These were possible due to the frequent participation of one of the authors in meetings of CESAN, SISAR, and SANEPAR. During these opportunities, participants were conducted to rural communities, where the local organization would provide an overview of their situation regarding financial, technical, and managerial elements. On these occasions, non-structured interviews were conducted to elucidate the actual organizational arrangements of the community. On the occasions of the VI and VII Latin-American Community Management Meetings, in Chile and Peru, respectively, non-structured interviews were also conducted with attendants involved in the rural water sector of Brazil and Ecuador.

\subsection{Comparison of Stakeholders' Responsibilities and Organizational Levels' Existence}

For the comparison of the case-studies mentioned, the data collected were tabulated into three main groups representing the Implementation, Operation \& Maintenance (OEM), and Management phases. Subsequently, the responsibilities assigned to each stakeholder on each case studied were verified, enabling an analysis of the organizational levels that each locality presents and how different stakeholders share responsibilities through the entire life cycle of a rural water supply system. This comparison allows a better understanding of the possibilities associated with the presence of the second and third organizational levels, as these associations could offer additional support to maintain persistent water services. 


\section{Results}

The emergence of the community management of rural water supply topic was observed due to the low number of scientific publications regarding the locations selected to compose the current work. In-depth analyses of the organizational structures of the rural water supply sector in Brazil and Ecuador and their successfulness are scarce, thus, technical information or indicators able to provide an in-depth representation of the scenario of each case studied, as water-quality data, frequency of breakdowns, or frequency of meetings, could not be collected.

\subsection{Community Management of Water Supply in Latin America}

National schemes established to pursue the universalization of water access in rural areas vary significantly through Latin American nations. They usually build on the main principles highlighted by specialists as determinants of positive outcomes of the community management of rural water supply systems, ensuring community participation [11,36,37], offering external support [25,38], and training managers and operators to perform daily tasks [28]. However, local contexts have been recurrent barriers for the establishment of water systems able to provide high-quality services to their users continuously, especially those related to political environments unable to recognize a community organization's ability to function as a service provider [37]. Some rural settlements in Latin America have been able to overcome local singularities, resulting in efficient water services able to provide users with reliable drinking water, whilst others have failed to maintain even minimum standards. These cases are still underexploited by the scientific community, whereas a few case-studies have been published regarding countries such as Colombia, Costa Rica, Nicaragua, and Paraguay, for example. From these papers, it is evident that the organizational levels Castillo [19] identifies as critical to community management's continuous functionality have obtained recognition among Latin American nations.

The establishment of these organizational levels, however, must encourage community organizations' enrollment through the maintenance of an active environment for problem solving regarding political, technical, and managerial aspects. In Paraguay, most "Juntas de Saneamiento" (sanitation boards), which are the entities accountable for the operation and management of rural water systems, tend to ignore the existence of regional associations and of the national federation. According to Álvares Prado [39], high annual fees and the perception that being part of the association generates minimal benefits have contributed to a low number of sanitation boards joining the second and third organizational level of the country.

In Nicaragua, the "Comites de Agua Potable y Saneamiento" (CAPS) have grown from unofficial community organizations which operated and maintained rural water systems to legally recognized entities under federal law. Initially, incentives to expand rural water supply systems in Nicaragua came from NGOs and international institutions, which would leave CAPS accountable for the OEM during the post-construction phase. Thus, CAPS would operate in isolation and informally. Despite this, CAPS' operators and managers were able to maintain water services continuously as a consequence of their commitment to users. Eventually, NGOs and multi-lateral organizations promoted the creation of a network involving several CAPS as a strategy to include their demands in national decision-making processes, supporting the existence of an association beyond the first organizational level. In 2010, CAPS were able to participate in the development of "The Special CAPS Law", which recognized them as service providers and, consequently, increased their institutional strength $[40,41]$.

In Colombia, liabilities associated with water committees' formalization have influenced part of the community organizations remaining illegal. Under federal law, water committees must hold the same responsibilities as private service providers, which is considered unfair by several community organizations [42]. Despite this, a number of water committees of rural settlements are formalized throughout the country. Searching for increased recognition in decision-making processes at a regional level, these committees have assembled to form second-level organizations, such as Asociación de Acueductos Comunitarios de Colombia (AQUACOL), Asociación Municipal de Acueductos de 
Dosquebradas (AMAC), and Federación de Acueductos de Risaralda (FACORIS). Their formalization holds some benefits, as the possibility to receive external support from governmental agencies. This support, however, is not continuous and is only provided when the water committees face some difficulties [43]. To reach further influence in political planning, these associations created the National Confederation of Rural Water Supply in 2015 and have been able to increase rural water supply recognition and improve political planning in the sector [44].

While other Latin American countries present similar examples of associations of second and third levels, such as Ecuador and Brazil, which will be described further in this paper, some nations still rely on the singular presence of local community organizations. In Peru, "Juntas Administradoras de Servicios de Saneamiento" (JASS) operate and maintain water systems individually, relying exclusively on support delivered by local governments [45]. Rural communities in Costa Rica follow a similar outline, where "Asociaciones Administradoras de Sistemas de Acueductos y Alcantarillados Sanitarios" (ASADAS) are responsible for water systems and have not assembled to create organizational levels beyond the first $[46,47]$.

\subsection{Community Management of Water Supply in Ecuador}

The establishment of the 2008's constitution initiated a water sector reform in the country, followed by several milestones. According to the document, privatization of water supply services is prohibited, being the public sector and community organizations responsible for the provision of drinkable water to the population [48]. In 2010, as stated in Dupuits [49], the National Water Secretariat (SENAGUA) was formed as a national agency aiming for the integration of stakeholders to increase institutional performance in decision-making regarding water resources. In the same year, the Organic Code of Territorial Organization, Autonomy and Decentralization (COOTAD) was created as an important legal mark to stimulate the development of partnerships between community organizations and decentralized autonomous governments (GADs) and to aid SENAGUA's efforts [50]. The document promotes integration between different levels of the public sector along with community participation in decision-making processes regarding water governance at the national, state, and local levels [51]. Another major step in this context was the creation of the Network of Social and Community Organizations of Water Management of Ecuador (ROSCGAE), which consists of a national association of community organizations established to improve their recognition among decision-makers [49]. Moreover, in 2014, the Organic Law of Hydric Resources and Water Uses was developed, reaffirming the role of SENAGUA as the national authority of water issues, also being responsible for articulating stakeholders at the national level. Besides, the document assigned accountabilities at the local level, clarifying the duties of community organizations and GADs [49,52].

The joint action of legislation, SENAGUA, local communities, and GADs favored the enhancement of water management in Ecuador, especially in some isolated areas of the country. Recent data regarding the number of community associations currently functioning are scarce; however, in 2010, over 6,800 community associations represented more than 2.7 million people in rural areas [50]. The associations are identified as "Juntas Administradoras de Água Potable y Alcantarillado" (JAAP); however, they are referred to with other names, depending on the region of the country [53]. Local conditions where these community associations operate vary significantly, demanding several adjustments of their basic framework to consider social, cultural, and economic aspects of each location. While some of these associations are able to sustain their management and physical systems efficiently, others demonstrate several fragilities and fail to provide the service continuously. According to Dupuits [49], despite the advancements made in the last decade towards more efficient water management policies and approaches, a number of local governments face several institutional difficulties in supporting local communities to maintain the water services continuously. SENAGUA also plays an essential role in these failures, as it does not supply community organizations with the necessary financial and management assistance. 
While the public sector is responsible for developing policies and regulations to support water management and for the construction and control of water systems when feasible, community associations are responsible for the protection of rivers and springs, along with the management and maintenance of water systems when public entities' services are expensive [52]. Foro de Los Recursos Hídricos [53] states that community organizations are non-profitable and operate in rural and isolated areas only to benefit these neglected populations, aiming at communities' welfare. However, costs associated with the operation and management of these water systems are high, as it involves energy bills, staff payment, and equipment maintenance. To cover these costs, community associations usually establish monthly fees for users [52,53].

Both the community and public management models have unique characteristics with different principles and goals. Despite some recurrent issues, community management represents a valuable and positive alternative for rural communities in Ecuador. According to Foro de Los Recursos Hídricos [53], once the community is responsible for managing the system, there is a larger participation and commitment of members, producing visible results and enabling a greater efficiency in terms of problem solving. Additionally, once the community is actively participating in the construction and management of the system, there is a direct relationship between users, water resources, and catchments, enhancing people's awareness and contributing to the protection of springs and the environment. The decision-making process also involves all association members, resulting in decisions that consider interests of the entire community.

However, articulation issues may occur among community organizations and external entities, jeopardizing the success of associations and compromising technical support, even though there are some iconic partnership examples in Ecuador, such as CENAGRAP [19]. It is also difficult to establish boundaries concerning the jurisdiction of each organization. Foro de Los Recursos Hídricos [53] points out that another major issue affecting community management systems in Ecuador is the absence of financial resources required to operate and manage the systems. To tackle this situation, either the "Juntas" seek support from decentralized governments, NGOs and international institutions, or they establish fees for the services, which in general are not enough to cover operational costs [50]. Furthermore, "Juntas" are currently relying on a management framework that presents several duties among members regarding the management of the water system. Besides, Ecuador's government requires several legal obligations for the legalization of these community organizations, which usually are not met due to the lack of expertise of community members. Therefore, many "Juntas" function under illegal conditions. Another important issue present in several community organizations in Ecuador is the low engagement ratio of women in decision-making as their value is not socially recognized. They are usually assigned to secondary duties, while men remain at a higher hierarchy level [53].

Even with several fragilities associated with the water resources sector in Ecuador regarding the water supply in isolated communities, some approaches have resulted in positive outcomes. Next, an emblematic case of partnership in the management of water supply in the country is presented.

\subsubsection{Emblematic Partnership in Ecuador: CENAGRAP}

The Center of Support for the Rural Management of Drinking Water (CENAGRAP) was established in 2002 through a joint venture among the city council, NGOs, and officialized "Juntas" of the Cañar district $[32,49,50,53]$. The inhabitants of the region have historically faced extremely poor life conditions and malnutrition, evidencing a critical singularity to be accounted for in the development of community management models in the location. Initially, CENAGRAP embraced 14 "Juntas"; however, this number has grown beyond 90 [54], favoring thousands of families and displaying the success of the approach.

According to Protos-Cedir [50] and Foro de Los Recursos Hídricos [53], external support from public agencies occurs through legal assistance in operation and licensing processes, the provision of financial resources for maintenance of the water systems, and the lease of public domains to build the 
necessary physical structure. In addition, governmental agencies are often performing activities along with other stakeholders to promote the awareness of water resources. Furthermore, the responsibilities allocated to CENAGRAP comprise the execution of preventive maintenance and inspections on a regular basis, provision of administrative support, and internal conflicts and inventory management. When specific equipment is necessary for system maintenance, CENAGRAP must provide fair prices aligned with each association budget. Finally, management of the water systems is a duty of the "Juntas", which operate individually for their specific communities. However, their integration is extremely encouraged through the conduction of regular assemblies where participants are able to share experiences and results.

CENAGRAP's methodology builds on strategies to consolidate community systems' sustainability by approaching several essential aspects, as gender, participation, and capacity building. Women's involvement is encouraged throughout the entire system, from basic tasks to decision-making processes, as a form of providing an active voice to all genders. Participation is also considered a fundamental approach as it has the potential to create a sense of ownership valuable to maintain a high-quality service for its users. Moreover, the promotion of capacity building initiatives comprises an important strategy to develop and strengthen the technical, administrative, and operational skills of technicians [50]. A critical aspect related to CENAGRAP's results consists of the articulation between decision-makers, which has enabled the creation of an information flow regarding financial, technical, and management aspects [32]. Consequently, better strategies towards rural water management are possible, maintaining systems' sustainability.

\subsection{Community Management Models of Water Supply in Brazil}

One of the key actors in rural water supply management in Brazil is the National Health Foundation (FUNASA), a federal government agency accountable for supporting the implementation of strategies to expand water and sanitation access to remote communities since its creation in 1991 [54]. FUNASA has assisted several local communities throughout the Brazilian territory, following a broad framework developed by its specialists which accounts for economic, institutional, environmental, and social aspects [55]. Their efforts in water access expansion, however, only received legal support in 2007, when Law $n^{\circ} 11,445 / 2007$ established the national guidelines for water supply management [56]. Through this law, the federal government is committed to pursuing the universalization of drinkable water access and reinforcing the necessity to provide safe water without legal, economic, physical, or cultural barriers. The national guidelines determined that water services are a liability of local governments. The municipalities, however, are able to concede these services to either private and public entities through the establishment of legal contracts or community organizations without the necessity of legal arrangements [56]. The community-based model of water resources management is an approach significantly applied in some states of the country and FUNASA recognizes it as an important approach applied nationally. It possesses an important value regarding drinkable water provision to isolated and rural communities in Brazil, as it is estimated that only $30.33 \%$ of households of these localities are connected to any type of water system [57].

In 2013, the Cities Ministry developed the National Water and Sanitation Plan (PLANSAB), creating plans of action and targets to address the premises determined in Law $n^{\circ} 11,445 / 2007$. Regarding rural water supply management, its main target consists of providing drinkable water access to $80 \%$ of households in these areas. PLANSAB was responsible for indicating the fragilities associated with water and sanitation services in the country, recognizing the differences between remote communities and urban areas. The document acknowledges the necessity to create innovative approaches concerning technological and management aspects, adapting the conventional strategies applied in urban areas to rural contexts [58]. Additionally, according to PLANSAB [58], these approaches must involve community participation, the development of environmental awareness among users, and capacity-building regarding technical and management aspects in order to achieve 
the best results. Considering the principles and legal structure developed, FUNASA's actions have been able to prioritize areas where water safety is the most threatened.

\subsubsection{SISAR-CE Model}

In Brazil, the Integrated System of Rural Sanitation (SISAR) has stood out in rural water supply management, maintenance, and operation in the Ceará state. It consists of an NGO created in 1996 to assemble representatives from community organizations, and state and city councils, promoting an optimized communication channel for decision-making assistance. Ceará's State Policy recognizes SISAR as a legal approach to tackle water supply difficulties in rural locations, granting permission for entities formed by several local communities to manage water supply systems. In 2017, SISAR was present in 1,419 communities within 146 cities, providing support for water treatment and distribution to 551,500 inhabitants and presenting $84 \%$ of its physical connections active $[20,59,60]$. The Water and Wastewater Company of Ceará (CAGECE) and the World Bank are responsible for providing public and financial support, respectively. SISAR is considered a great example of best practices applied to rural water supply in Latin America, since it has been capable of reaching a great number of communities in the state and providing regular access to drinkable water [61].

SISAR proposes a management model committed to community engagement alongside public participation. Innovations in technical, administrative, and social areas are also encouraged in order to improve service efficiency and quality. As a form of innovation, methodologies not applied in rural areas are often being tested and, if successful, applied. Knowledge and experience exchange are endorsed as significant contributors to the service's quality, as they are able to supply decision-makers with a wider perspective once they become aware of external situations faced by technicians from outside systems [61]. Through the strategies presented, SISAR searches for sustainability to continuously ensure its functionality.

To extend water access to communities, SISAR follows a basic framework that comprises essential steps for the success of the process. Firstly, communities are accountable for the creation of community organizations with an outlined structure and hierarchy to represent their entire society's interests. Then, the Rural Development Office (SDA) joins stakeholders during planning, acting on fundraising from development agencies and the state government. After the strategies have been discussed and defined, the state government is responsible for designating private entities to the construction of the system, and it is CAGECE's function to supervise this process. Lastly, the operational phase takes place, and it is the community organization's duty to nominate a member responsible for operation and maintenance of the system once the technician is properly capacitated by SISAR's staff. During this stage, water quality control and equipment maintenance are responsibilities assigned to SISAR [61].

According to Castro [10], SISAR reaches effectiveness as it answers the needs of the majority of residents in each community and improves their quality of life. The same author mentions the community organization as an evolution; however, he acknowledges that its maintenance remains a challenge to the board of community organization's directors.

\subsubsection{CESAN-ES Model}

In Espírito Santo State, Sanitation Company of Espírito Santo (CESAN) is responsible for water and sanitation services, being a mixed economy company established in 1968 through a collaboration of the state government and private groups. It comprises water catchment, treatment, distribution, collection, and wastewater treatment. It is also responsible for studies and projects related to systems' expansion, reaching 52 of the 78 cities in Espírito Santo. According to Azevedo [61], only one city from the remainder receives sanitation services by a private company. The Autonomous Water and Wastewater Service (SAAE), a municipal agency, is responsible for water and sanitation services of the other twenty-five cities. In municipalities where CESAN has concession, as is seen in several places of the country, water systems are only able to effectively reach those users situated in larger urbanized areas. In 1991, however, the "Pró-Rural" program was created through Resolution n²,745 as a division 
of CESAN in a partnership involving the company, city councils, and local communities from Espírito Santo. Its main target is to support the development of water systems in geographically isolated locations with population numbers between 50 and 1,500 residents where CESAN has concession; however, it does not possess the financial resources necessary to provide quality services. Until 2014, 218 communities had received access to drinking water and 39 had their wastewater treated through the Pró-Rural initiative, representing 48 of the 52 municipalities where CESAN has concession for the services [61].

According to CESAN's framework, firstly, CESAN's environmental analysts mobilize the community through meetings composed of a minimum of three inhabitants for the creation of the community's water management committee. These committees are responsible for the management, operation, and maintenance of the water system, counting on the appropriate assistance of external stakeholders. Once the community committee is established, system's construction initiates with technical support from CESAN and financial support from the state government or from a partnership between the State Office for Sanitation, Dwelling and Urban Development (SEDURB) and city councils [61]. After the completion of the building process, the community committee becomes responsible for the maintenance of the system's quality. The committee charges monthly fees to users to subsidy expenses with the energy cost, chemical compounds, operator's wage, preventive maintenance, and equipment replacement. Some municipalities assume energy and operational costs, which is not a scenario reproduced in every case. Thus, it is possible to verify a specific operation dynamic regarding CESAN's approach to provide isolated communities with drinking water services [61].

As a strategy to improve service quality, CESAN is constantly searching for the application of technological and administrative innovations. Recently, public sector and community committees have been including micro-measurement technologies as a method to enhance revenue, reduce losses, and provide equitable prices for their users [61].

\subsubsection{SANEPAR-PR Model}

The Sanitation Agency of Paraná (SANEPAR) is the agency responsible for water and sanitation services in the state of Paraná, Brazil. In a joint action with the State Government, municipalities, and local communities, the agency conducts the Rural Sanitation Program, which focuses on the improvement of quality of life of rural populations [61,62]. Efforts to supply rural communities with drinking water initiated with the "Pró-Rural" program, which performed from 1981 until 1994. However, SANEPAR developed several other programs as strategies to grant water access to communities in Paraná, and was able to reach 412,412 inhabitants by 2014 [63].

SANEPAR's target communities for the development of water supply systems are those located in rural areas with dispersed settlements. According to SANEPAR [62], the execution of these systems depends on communities' interest, as a formal request letter with the community's name, location, and number of houses must be sent to SANEPAR's leader for process commencement. Following the recognition of the community's interest in SANEPAR's services, the agency performs a technical and social diagnosis of the area along with the municipality, approaching aspects regarding public health, financial feasibility, and physical conditions of the area. For the installation of the water supply system and its management and maintenance, either SANEPAR is responsible for providing financial support along with the municipality or FUNASA finances the expenditures [62]. Moreover, community organizations charge monthly fees to users of the water system as a means to cover costs relating to energy, maintenance, and equipment replacement [61,62].

SANEPAR's accountability encompasses the development of the engineering project, acquisition of part of the materials and equipment necessary, provision of technical support during systems' implementation, assistance in the establishment of community organizations, encouragement of the community's involvement, capacity-building of the designated operators, and provision of chemical compounds for the commencement of operations [62]. A fundamental phase for the 
success of community managed water systems, which is the capacity-building process, involves recommendations for properly handling chemical compounds, instructions on the preparation of the chlorine solution used in the treatment and training for the operation, and maintenance of mechanical and electromechanical components of the system. The capacity-building process also includes other actions including active engagement with the community, such as environmental and sanitary education, the creation of guidelines to assess the performance of the system and the operators, equipment maintenance, and safety standards and procedures.

The municipality's liability includes the provision of public lands for the construction of the water treatment plant, installation of the electric power grid, building the water treatment plant and distribution network, monitoring water quality standards, provision of technical and management support, and supplying chemical compounds for the continuity of operations. Also, the municipality has an essential role in promoting community engagement throughout planning, execution, and operation of the systems. The construction of the water treatment plant and distribution network traditionally includes the community's involvement in the excavation of ditches where the distribution network will be placed and in other areas where technical expertise is not essential, which is necessary to create a sense of ownership in the community regarding the water system [63]. In some cases, such as the installation of deep-water wells for water extraction, community engagement is replaced by professionalized staff. This is a common scenario in communities where SANEPAR operates, considering that the main source of water resources in these areas is from underground reservoirs. This type of water usually carries several chemical compounds detrimental to public health, requiring the employment of pressure filters for iron and manganese removal and equipment for sodium hypochlorite application.

Thus, the building process of the entire water system must include community, SANEPAR, and the municipality's engagement for the completion of an efficient service. Once the construction phase is finished, the water system is formally transferred to the municipality's possession. Afterwards, the municipality transfers the responsibility to operate and manage the system to the community, without ownership concession. Initially, the agency performs several technical inspections and meetings with the community organization to evaluate water quality standards and the efficiency of the community management model. Furthermore, the agency conducts satisfaction surveys as a means of assessing the effectiveness of the water service provided. Finally, SANEPAR's involvement terminates, returning only when the municipality requests the agency's assistance [63].

SANEPAR's model of providing drinking water to rural communities, however, possesses some vulnerabilities. There is no evidence of specialized professionals at the municipal level dedicated to providing support to community organizations. This aspect is essential for the maintenance of the system's functionality. Azevedo [61] also states several difficulties in the acquisition of chemical compounds for water treatment, consequently decreasing the quality of the water delivered to users. There are, however, some positive aspects visualized from SANEPAR's experiences. Women are actively participating in several community organizations along with other members of the community. This management model has been responsible for the identification and development of a number of leaders from these communities, enhancing personal skills. Moreover, some community organizations have efficiently applied the ideas proposed by SANEPAR to achieve high-level services, which has resulted in independence from the need of constant external support.

\section{Discussion}

The first organizational level was observed in all cases. This result was expected due to the nature of these management models, which rely on community organizations to manage, operate, and maintain water services in their communities. Some cases of multi-community approaches were verified in the case of the State of Ceará; however, the single community approach continues to be the most common situation. Castillo [19] recognizes the presence of the other two organizational levels as an important and necessary upgrade to community management models, which is a strategy still 
underexploited in several developing countries. In the cases studied, the State of Ceará and Cañar district exhibited a second organizational level, which could be one of the factors influencing their positive reviews, as seen in Schweizer \& Brethaut [31], Mastrángelo \& Almansa [32], and Garrido et al. [33]. Second level organizations have been proven to generate favorable outcomes, as seen by Romano [40] and Dupuits and Bernal [44], especially regarding political recognition. The third level, however, was only recognized in the case of Ecuador, where ROSCGAE is accountable for representing community organizations at a national level, which has the potential to further local communities' recognition of their countries in the political environment and allow them to participate in discussions about national guidelines in the water sector, as stated by Castillo [19].

The stakeholders involved in each community organization model described in the current paper and their accountabilities are demonstrated in Table 1. In every case studied, it is noticeable that external stakeholders are highly present during the Implementation phase. CESAN, SANEPAR, CAGECE, SISAR, and CENAGRAP maintain close contact with communities, as a consequence of the high demand for expertise to perform the construction and establishment of the systems. Municipalities' involvement during this phase varies considerably among the cases. Whilst municipalities hold few responsibilities in Espírito Santo, Paraná, and Ceará, there is a high engagement of GADs in the Cañar district, only omitting from the provision of technical support, which is provided by CENAGRAP. The second organizational level is identified in the Implementation phase in the cases of Ceará and Cañar through SISAR and CENAGRAP, respectively. Along with GADs, CENAGRAP holds an important role during this phase, as it aids in every responsibility demonstrated in Table 1. SISAR, however, has little participation during this phase, only contributing with operator employment and training. The third organizational level, however, is only present in the Cañar district, where ROSCGAE contributes to the political recognition and institutional support of communities.

Table 1. Responsibilities of each stakeholder during the Implementation, OEM (post-construction) and Management (post-construction) phases.

\begin{tabular}{|c|c|c|c|c|c|}
\hline & Responsibilities & Espírito Santo (CESAN) & Paraná (SANEPAR) & Ceará (SISAR) & Ecuador (CENAGRAP) \\
\hline \multirow{6}{*}{ 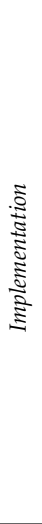 } & $\begin{array}{l}\text { Concession of land to } \\
\text { system construction }\end{array}$ & Municipality & Municipality & Municipality & GAD \\
\hline & $\begin{array}{l}\text { Technical support } \\
\text { and orientation }\end{array}$ & CESAN & SANEPAR & CAGECE & CENAGRAP \\
\hline & $\begin{array}{c}\text { Social and } \\
\text { environmental actions }\end{array}$ & CESAN & SANEPAR & SISAR & CENAGRAP/GAD \\
\hline & $\begin{array}{l}\text { Provision of resources or } \\
\text { funding mechanisms }\end{array}$ & Municipality/State & Municipality/SANEPAR & State & CENAGRAP/GAD \\
\hline & System construction & CESAN & Community/SANEPAR & CAGECE & $\begin{array}{c}\text { Community/ } \\
\text { CENAGRAP/GAD }\end{array}$ \\
\hline & $\begin{array}{l}\text { Operator employment } \\
\text { and training }\end{array}$ & $\begin{array}{c}\text { Municipality or } \\
\text { community/CESAN }\end{array}$ & $\begin{array}{l}\text { Municipality or } \\
\text { community }\end{array}$ & Community/SISAR & CENAGRAP/GAD \\
\hline \multirow{5}{*}{ 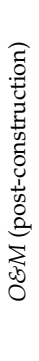 } & $\begin{array}{l}\text { Corrective and } \\
\text { preventive maintenance }\end{array}$ & - & Municipality & SISAR & $\begin{array}{l}\text { Community/ } \\
\text { CENAGRAP }\end{array}$ \\
\hline & Water quality control & Municipality & Municipality & SISAR & CENAGRAP \\
\hline & Fees collection & Community & Community & SISAR & - \\
\hline & $\begin{array}{c}\text { Regular technical } \\
\text { support }\end{array}$ & - & - & SISAR & $\begin{array}{l}\text { CENAGRAP / } \\
\text { GAD }\end{array}$ \\
\hline & $\begin{array}{c}\text { Clandestine connections } \\
\text { inhibition }\end{array}$ & Community & Community & Community & - \\
\hline
\end{tabular}


Table 1. Cont

\begin{tabular}{|c|c|c|c|c|c|}
\hline & Responsibilities & Espírito Santo (CESAN) & Paraná (SANEPAR) & Ceará (SISAR) & Ecuador (CENAGRAP) \\
\hline \multirow{6}{*}{ 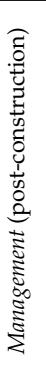 } & $\begin{array}{l}\text { OEM costs } \\
\text { establishment }\end{array}$ & Community & Community & SISAR & $\begin{array}{l}\text { Community/ } \\
\text { GAD }\end{array}$ \\
\hline & Spare parts supply & - & - & SISAR & CENAGRAP \\
\hline & Fees definition & Community & Community & SISAR & $\begin{array}{l}\text { CENAGRAP/ } \\
\text { GAD }\end{array}$ \\
\hline & $\begin{array}{c}\text { Financial resources } \\
\text { management }\end{array}$ & Community & Community & SISAR & CENAGRAP \\
\hline & $\begin{array}{l}\text { Administrative } \\
\text { assistance }\end{array}$ & - & - & SISAR & CENAGRAP \\
\hline & System ownership & - & Municipality & - & Community \\
\hline
\end{tabular}

The OEM and Management phases demonstrate the different paths that each community management model adopted. Espírito Santo and Paraná illustrate similar scenarios, where communities and municipalities appear as the only stakeholders assuming responsibilities to maintain water systems' functionality through time. The lack of regular technical support consists of a critical fragility associated with several water system breakdowns in the world $[14,15]$ and this is observed in these Brazilian states, as seen in Table 1. Therefore, relying on systems' management and maintenance of these two stakeholders highlights a critical error in water systems' sustainability in Brazil. Remote and rural communities in the country usually house inhabitants with low expertise, contributing to a lack of ability to manage water systems. Besides, considering the historical low administrative expertise that Brazilian municipalities present, their assistance is usually insufficient [27]. In Ceará and Cañar, however, the second organizational level remains greatly involved during the post-construction phases, along with communities and municipalities. CENAGRAP and SISAR assume important responsibilities, which are usually associated with community management successes, such as the provision of regular technical support and the execution of preventive and corrective maintenance [33].

Finally, following the path that each case-study has demonstrated, the Management phase in Espírito Santo and Paraná remains exclusively an accountability of communities and municipalities. Thus, the same fragilities associated with this scenario in the OEM phase apply to this situation. Ceará and the Cañar district continue to exhibit the presence of the second organizational level through the efforts of CENAGRAP and SISAR, which participate in several aspects in the Management phase. Their continuing assistance is essential to guaranteeing technical and administrative support provision to community organizations, which usually lack the expertise demanded to manage water supply systems. Thus, it is noticed that the second level has the potential to contribute to maintaining water systems' functionality through the entire life cycle of the community management model.

\section{Conclusions}

Community organizations and municipalities have demonstrated an ability to adequately maintain water supply systems in rural communities through joint initiatives with local governments, multi-lateral entities, and associations from the second and third organizational level. The efficiency and functionality of rural water services, however, are jeopardized when local governments and local communities are the only actors involved in $O \mathcal{E} M$, as demonstrated in Espírito Santo and Paraná. Some cases in Latin America have proven that exceptions occur; however, common institutional weaknesses intrinsic to Brazilian municipalities hinder the proper development of community organizations. The development of associations of community organizations representing a second organizational level as a form of facilitating technical and managerial support has proved to generate positive results in the system's functionality, as seen in Ceará and Cañar through the establishment of SISAR and CENAGRAP. This scenario requires commitment of the community organizations and local governments involved. To further promote institutional recognition of these organizations, the third level appears as an important body accountable for representing community organizations 
in decision-making processes, which contributes to maintaining legal support for water services in rural communities and to inserting local communities previously forsaken into national discussions. In Brazil, the creation of associations of the third organizational level could be a challenge considering the wide dimensions of Brazilian territory. In Ecuador, ROSCGAE has been able to improve community organizations' political importance and influence, which provides major contributions to their cause, such as the possibility of special taxations and advantages in licensing processes.

The presence of associations of community organizations reaching regional and national scales has been demonstrated to enable further possibilities of improvement for local communities. Beyond the cases studied in the current work, it is noticed that these associations are gaining importance among Latin American nations. Several countries have adhered to the creation of such associations, which have contributed to the restructuring of their enabling environment and, consequently, benefited local communities in the maintenance of rural water supply systems. Further investigation must be conducted to measure the real contributions of their presence; however, the scarcity of indicators able to illustrate the real conditions and evolution of the rural water supply sector in several developing countries is still a weakness in this study area.

Author Contributions: Conceptualization, A.V.M.M. and J.A.N.d.S.; Methodology, L.M.C.A. and N.d.S.Q.; Formal Analysis, A.V.M.M., L.M.C.A and N.d.S.Q.; Investigation, A.V.M.M., L.M.C.A. and N.d.S.Q.; Writing-Original Draft Preparation, A.V.M.M.; Writing—Review \& Editing, L.M.C.A and N.d.S.Q..; Visualization, L.M.C.A. and N.d.S.Q.; Supervision, A.V.M.M..; Project Administration, A.V.M.M.

Funding: This research received no external funding.

Conflicts of Interest: The authors declare no conflict of interest.

\section{References}

1. World Health Organization (WHO); United Nations Children's Fund (UNICEF). Progress on Drinking Water, Sanitation and Hygiene: 2017 Update and SDG Baselines; WHO/UNICEF: Geneva, Switzerland, 2017.

2. Kayser, G.L.; Amjad, U.; Dalcanale, F.; Bartram, J.; Bentley, M.E. Drinking water quality governance: A comparative case study of Brazil, Ecuador, and Malawi. Environ. Sci. Policy 2015, 48, 186-195. [CrossRef] [PubMed]

3. Rural Water Supply Network (RWSN). Rural Water Supply Network Strategy 2018-2023; RWSN: St. Gallen, Switzerland, 2018.

4. United Nations (UN). Sustainable Development Goal 6 Synthesis Report on Water and Sanitation; UN: New York, NY, USA, 2018.

5. United Nations General Assembly. Transforming Our World: The 2030 Agenda for Sustainable Development; United Nations General Assembly: New York, NY, USA, 2015.

6. Behnke, N.L.; Klug, T.; Cronk, R.; Shields, K.F.; Lee, K.; Kelly, E.R.; Allgood, G.; Bartram, J. Resource mobilization for community-managed rural water systems: Evidence from Ghana, Kenya, and Zambia. J. Clean. Prod. 2017, 156, 437-444. [CrossRef]

7. Hunter, P.R.; Macdonald, A.M.; Carter, R.C. Water Supply and Health. PLoS Med. 2010, 7, e1000361. [CrossRef] [PubMed]

8. Kleemeier, E. The impact of participation on sustainability: An analysis of the Malawi rural piped scheme program. World Dev. 2000, 28, 929-944. [CrossRef]

9. Whittington, D.; Davis, J.; Prokopy, L.; Komives, K.; Thorsten, R.; Lukacs, H.; Bakalian, A.; Wakeman, W. How well is the demand-driven, community management model for rural water supply systems doing? Water Policy 2009, 11, 696-718. [CrossRef]

10. Castro, S.V. Análise do Sistema Integrado de Saneamento Rural—SISAR, em sua Dimensão Político-Institucional, com Ênfase no Empoderamento das Comunidades Participantes. Ph.D Thesis, Universidade Federal de Minas Gerais (UFMG), Belo Horizonte, MG, Brazil, 2015.

11. Harvey, P.A.; Reed, R.A. Community-managed water supplies in Africa: Sustainable or dispensable? Comm. Dev. J. 2007, 42, 365-378. [CrossRef]

12. Chowns, E. Is community management an efficient and effective model of public service delivery? Lessons from the rural water supply sector in Malawi. Public Adm. Dev. 2015, 35, 263-276. [CrossRef] 
13. Briscoe, J.; Deferranti, D. Water for Rural Communities: Helping People Help Themselves; World Bank: Washington, DC, USA, 1988.

14. Hutchings, P.; Chan, M.Y.; Cuadrado, L.; Ezbakhe, F.; Mesa, B.; Tamekawa, C.; Franceys, R. A systematic review of success factors in the community management of rural water supplies over the past 30 years. Water Policy 2015, 17, 963-983. [CrossRef]

15. Klug, T.; Shields, K.F.; Cronk, R.; Kelly, E.; Behnke, N.; Lee, K.; Bartram, J. Water system hardware and management rehabilitation: Qualitative evidence from Ghana, Kenya, and Zambia. Int. J. Hyg. Environ. Health 2017, 220, 531-538. [CrossRef]

16. Mc Common, C.; Warner, D.; Yohalem, D. Community Management of Rural Water Supply and Sanitation Services; The International Bank for Reconstruction and Development: Washington, DC, USA, 1990.

17. Sara, J.; Katz, T. Making Rural Water Supply Sustainable: Report on the Impact of Project Rules; World Bank: Washington, DC, USA, 2005.

18. Carrasco, W.; Bernal, A. Planificación y concepción de los servicios de agua y saneamiento en áreas rurales de Latinoamérica y el Caribe (LAC). In Proceedings of the Congreso Interamericano de Agua Potable y Saneamiento Rural, Cuenca, Ecuador, 6-9 August 2014.

19. Castillo, O.R. El asociacionismo rural y las capacidades de los operadores locales en Centroamérica. In Los modelos de Gestión Comunitária del água y Saneamiento en Latinoamérica y el Caribe: Ventajas, Limites y Oportunidades, 1; Universidad Autónoma de Chile: Santiago, Chile, 2016; pp. 57-68.

20. Barde, J.A. What Determines Access to Piped Water in Rural Areas? Evidence from Small-Scale Supply Systems in Rural Brazil. World Dev. 2017, 95, 88-110. [CrossRef]

21. Braimah, I.; Amponsah, O.; Asibey, M.O. The effectiveness of the local management systems of rural water facilities for sustainable service delivery: A case study of the Sekyere East District, Ghana. Sustain. Water Resour. Manag. 2016, 2, 405-418. [CrossRef]

22. Leclert, L.; Nzioki, R.M.; Feuerstein, L. Addressing Governance and Management Challenges in Small Water Supply Systems-The Integrity Management Approach in Kenya. Aquat. Procedia 2016, 6, 39-50. [CrossRef]

23. World Health Organization (WHO). Developing Drinking-Water Quality Regulations: General Guidance with a Special Focus on Countries with Limited Resources; WHO: Geneva, Switzerland, 2018.

24. Rautanen, S.L.; White, P. Portrait of a successful small-town water service provider in Nepal's changing landscape. Water Policy 2018, 20, 84-99. [CrossRef]

25. Schweitzer, R.W.; Mihelcic, J.R. Assessing sustainability of community management of rural water systems in the developing world. J. Water Sanit. Hyg. Dev. 2012, 2. Available online: http://washdev.iwaponline. com/cgi/doi/10.2166/washdev.2012.056 (accessed on 17 October 2018). [CrossRef]

26. Amjad, U.Q.; Ojomo, E.; Downs, K.; Cronk, R.; Bartram, J. Rethinking Sustainability, Scaling Up, and Enabling Environment: A Framework for Their Implementation in Drinking Water Supply. Water 2015, 7, 1497-1514. [CrossRef]

27. Kativhu, T.; Mazvimavi, D.; Tevera, D.; Nhapi, I. Implementation of Community Based Management (CBM) in Zimbabwe: The dichotomy of theory and practice and its influence on sustainability of rural water supply systems. Phys. Chem. Earth 2018, 100, 247-257. [CrossRef]

28. Madrigal, R.; Alpízar, F.; Schlüter, A. Determinants of Performance of Community-Based Drinking Water Organizations. World Dev. 2011, 39, 1663-1675. [CrossRef]

29. McNicholl, D.; McRobie, A.; Cruickshank, H. Characteristics of stakeholder networks supporting local government performance improvements in rural water supply: Cases from Ghana, Malawi, and Bolivia. Water Altern. 2017, 10., 541-561.

30. Pereira, T.S.T.; Heller, L. Planos municipais de saneamento básico: Avaliação de 18 casos brasileiros. Engenharia Sanitária e Ambiental 2015, 20, 395-404. [CrossRef]

31. Schweizer, R.; Brethaut, C. A Critical Approach to International Water Management Trends: Policy and Practice, 1st ed.; Palgrave Macmillan: Geneva, Switzerland, 2018.

32. Mastrángelo, P.; Almansa, M. Water and sanitation: Innovations you didn't know were from Latin America and the Caribbean. Inter-American Development Bank. [s.l: S.n.]. Available online: https:/ /www.faa.gov/ data_research/aviation/aerospace_forecasts/media/FY2017-37_FAA_Aerospace_Forecast.pdf (accessed on 14 October 2018).

33. Garrido, J.; Rocha, W.; Gambrill, M.; Collet, H. Estudo de modelos de gestão de serviços de abastecimento de água no meio rural no Brasil_Parte 1: Relatório Principal; World Bank: Brasília, Brazil, 2016. 
34. Webster, J.; Watson, R.T. Analyzing the Past to Prepare for the Future: Writing a Review. MIS Q. 2002, 26, xiii.

35. Moher, D.; Liberati, A.; Tetzlaff, J.; Altman, D.G.; The PRISMA Group. Preferred Reporting Items for Systematic Reviews and Meta-Analyses: The PRISMA Statement. PLoS Med. 2009, 6, e1000097. [CrossRef]

36. Hall, D.M.; Gilbertz, S.J.; Anderson, M.B.; Ward, L.C. Beyond "buy-in": Designing citizen participation in water planning as research. J. Clean. Prod. 2016, 133, 725-734. [CrossRef]

37. Moriarty, P.; Smits, S.; Butterworth, J.; Franceys, R. Trends in rural water supply: Towards a service delivery approach. Water Altern. 2013, 6, 329-349.

38. Kayser, G.L.; Moomaw, W.; Portillo, J.M.O.; Griffiths, J.K. Circuit Rider post-construction support: Improvements in domestic water quality and system sustainability in El Salvador. J. Water Sanit. Hyg. Dev. 2014, 4, 460. Available online: http:/ / washdev.iwaponline.com/cgi/doi/10.2166/washdev.2014. 136 (accessed on 29 January 2019). [CrossRef]

39. Álvarez Prado, L. Rural water sustainability in Latin America and the Caribbean the sanitation boards in Paraguay. Ph.D Thesis, Universitat Autònoma de Barcelona (UAB), Barcelona, Spain, 2015.

40. Romano, S.T. Building Capacities for Sustainable Water Governance at the Grassroots: “Organic Empowerment" and Its Policy Implications in Nicaragua. Soc. Nat. Res. 2017, 30, 471-487. Available online: http:/ / dx.doi.org/10.1080/08941920.2016.1273413 (accessed on 29 January 2019). [CrossRef]

41. Baquero, O.F.; Núñez, P.N.; Meza, J.R.; de Palencia, A.J.F.; Foguet, A.P.; Colmenero, A.G. Caracterización de la acción colectiva para la gestión de los recursos hídricos en la región central de Nicaragua. VI Congreso Universidad y Cooperación al Desarrollo Valencia, 2013; pp. 1-15. Available online: http://www. sextocongresocud.es/ (accessed on 28 January 2019).

42. Brown, S.; Roa, M.; Roa, C. Jerarquía de vulnerabilidades de las organizaciones comunitarias de agua en Colombia. Gestión y Ambiente 2015, 18, 51-79.

43. Smits, S.; Rojas, J.; Tamayo, P. The impact of support to community-based rural water service providers: Evidence from Colombia. Water Altern. 2013, 6, 384-404.

44. Dupuits, E.; Bernal, A. Scaling-up water community organizations: The role of inter-communities networks in multi-level water governance. Flux 2015, 99, 19-31. [CrossRef]

45. Calzada, J.; Iranzo, S.; Sanz, A. Community-Managed Water Services: The Case of Peru. J. Environ. Dev. 2017, 26, 400-428. [CrossRef]

46. Dobbin, K.B.; Sarathy, B. Solving Rural Water Exclusion: Challenges and Limits to Co-Management in Costa Rica. Soc. Nat. Resour. 2015, 28, 388-404. [CrossRef]

47. Madrigal-Ballestero, R.; Alpízar, F.; Schlüter, A. Public perceptions of the performance of community-based drinking water organizations in Costa Rica. Water Resour. Rural Dev. 2013, 1-2, 43-56. [CrossRef]

48. Constitución Política de la República del Ecuador; Asamblea Constituyente, Asaemblea Nacional de Ecuador: Quito, Ecuador, 2008.

49. Dupuits, E. From multi-level governance to scalar politics: Water community networks challenging neo-extractivist governmental institutions in Ecuador. In A Critical Approach to International Water Management Trends: Policy and Practice, 1; Bréthaut, C., Schweizer, R., Eds.; Palgrave Macmillan: Geneva, Switzerland, 2018; pp. 97-122.

50. Protos-Cedir. Yakukamay. Alianza Público-Comunitaria: La experiencia desde el CENAGRAP; CENAGRAP/PROTOSCEDIR: Cañar, Ecuador, 2011.

51. Código Orgánico de Organización Territorial, Autonomía y Descentralización-COOTAD; Presidência de la Republica de Ecuador: Quito, Ecuador, 2010.

52. Ley Orgánica de Recursos Hídricos, Usos y Aprovechamiento del Agua; Presidência de la Republica de Ecuador: Quito, Ecuador, 2014.

53. Foro de los Recursos Hídricos. La gestión comunitaria del agua para consumo humano y el saneamiento en el Ecuador: Diagnóstico y propuestas; Foro Nacional de Recursos Hídricos: Quito, Ecuador, 2013.

54. Fundação Nacional de Saúde (FUNASA). Manual de Saneamento, 4th ed.; FUNASA: Brasília, DF, Brazil, 2017.

55. Teixeira, J.B. Saneamento Rural no Brasil. In Panorama do Saneamento Basico no Brasil: Cadernos Temáticos para o Panorama do Saneamento Básico no Brasil, 1; Rezende, S.C., Ed.; Ministério das Cidades/Secretaria Nacional de Saneamento Ambiental: Brasília, DF, Brazil, 2011; Volume 7, pp. 220-279.

56. Lei 11.445, de 5 de janeiro de 2007; Presidência da República do Brasil: Brasília, Brazil, 2007.

57. Instituto Brasileiro de Geografia e Estatística (IBGE). Pesquisa Nacional por Amostra de Domicílios: Síntese de Indicadores; IBGE: Rio de Janeiro, RJ, Brazil, 2014. 
58. Ministério das Cidades. Plano Nacional de Saneamento Básico-PLANSAB; Ministério das Cidades: Brasília, DF, Brazil, 2013.

59. Alves, F.G.C.; Araújo, F.T.V. Sistemas de abastecimento em comunidades rurais do semiárido: A implantação do SISAR em Cristais, Cascavel, CE. Rev. Tecnol. 2016, 37, 78-86. [CrossRef]

60. Ataíde, G.V.T.L.; Moraes, L.R.S.; Borja, P.C. Autogestão em Saneamento Básico no Brasil: Experiências e Aprendizados. In Proceedings of the XVI Exposição de Experiências Municipais em Saneamento, Maringá, PR, Brazil, 10-15 June 2012.

61. Azevedo, M. Experiências do saneamento rural Espírito Santo Pró-Rural/ CESAN. Presented at VII Seminário Nacional de Saneamento Rural, Vitória, ES, Brazil, 10-13 November 2014.

62. Rusch, I.L. A Experiência da Sanepar com Sistemas de Abastecimento de Água em Pequenas Comunidades Rurais. In Proceedings of the VII Seminário Nacional de Saneamento Rural, Vitória, ES, Brazil, 10-13 olNovember 2014.

63. Companhia de Saneamento do Paraná (SANEPAR). Manual Orientativo-Prograna SANEPAR Rural; SANEPAR: Curitiba, PR, Brazil, 2016.

(C) 2019 by the authors. Licensee MDPI, Basel, Switzerland. This article is an open access article distributed under the terms and conditions of the Creative Commons Attribution (CC BY) license (http://creativecommons.org/licenses/by/4.0/). 